Revue d'études américaines. American Studies Journal

$2 \mid 2011$

Sport et société / Animals and the American

Imagination

\title{
Coloring Their World: Americans and Decorative Color in the Nineteenth Century
}

\section{Kelly Wright}

\section{(2) OpenEdition}

\section{Journals}

Édition électronique

URL : https://journals.openedition.org/transatlantica/5612

DOI : $10.4000 /$ transatlantica.5612

ISSN : 1765-2766

Éditeur

Association française d'Etudes Américaines (AFEA)

Référence électronique

Kelly Wright, "Coloring Their World: Americans and Decorative Color in the Nineteenth Century »,

Transatlantica [En ligne], 2 | 2011, mis en ligne le 10 mai 2012, consulté le 31 janvier 2023. URL : http:// journals.openedition.org/transatlantica/5612 ; DOI : https://doi.org/10.4000/transatlantica.5612

Ce document a été généré automatiquement le 31 janvier 2023.

\section{cc) (†)}

Creative Commons - Attribution - Pas d'Utilisation Commerciale - Pas de Modification 4.0 International - CC BY-NC-ND 4.0

https://creativecommons.org/licenses/by-nc-nd/4.0/ 


\section{Coloring Their World: Americans and Decorative Color in the Nineteenth Century}

\section{Kelly Wright}

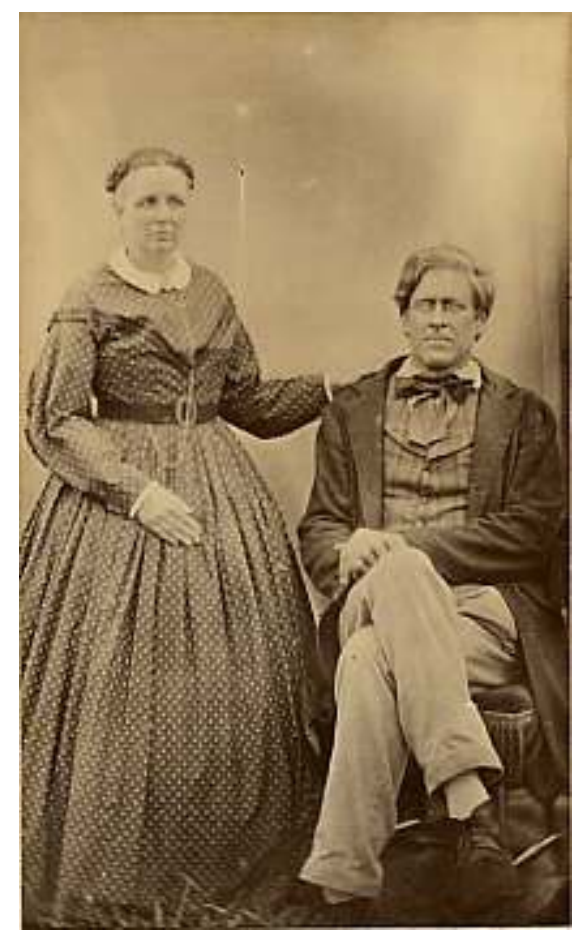

Fig. 1. Wet-collodion photograph by R. R. Morganweck. Courtesy of Virginia and Michael Mescher, 1999.

When in 1999 Civil War re-enactors and sutlers Michael and Virginia Mescher dressed for a period portrait using a mid-nineteenth century photographic method, they fussed more over their hair than their clothes [Fig. 1]. After all, as serious historical interpretors they had studied period dress and knew their outfits made of reproduction 
fabrics were appropriate choices for representing the year 1863. What they did not know was how much the wet collodion photographic process would alter the appearance of their clothes. The vibrant plaid of Michael's vest washed out, his bright gold cravat turned black, and the patterns of Virginia's pretty wine-red dress dissolved into a muddy sea of bodice and skirt.

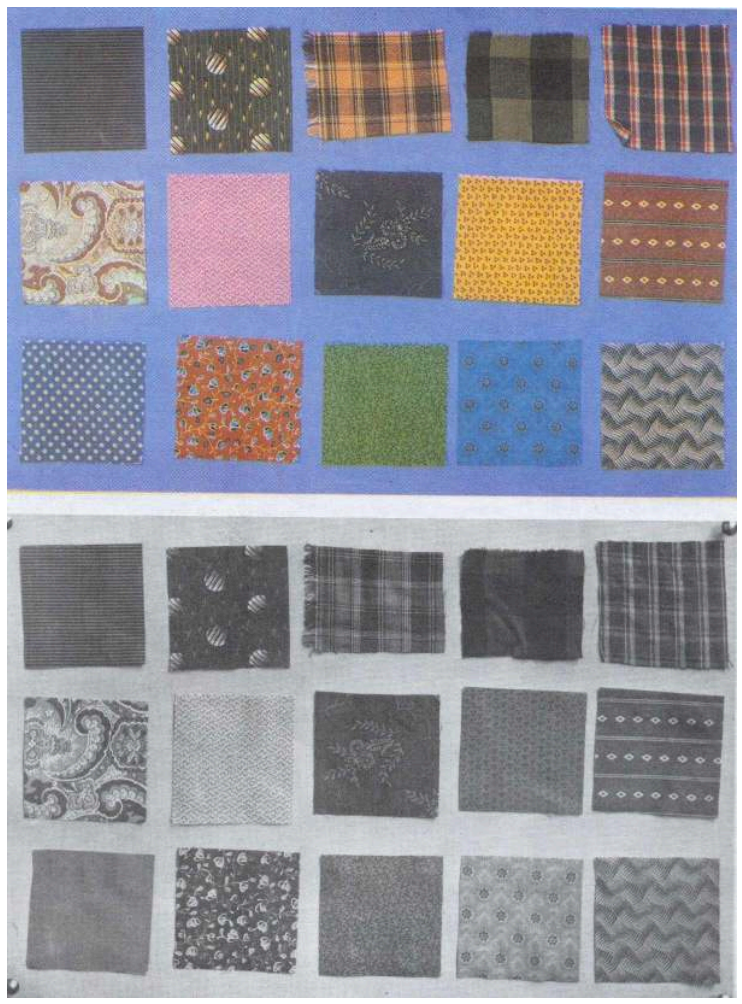

Fig. 2. Swatches of period fabrics photographed in color with a modern camera, and in black and white through the wet collodion process. Scully \& Osterman Studio. 1997.

2 Still the period photograph was successful, and the subjects looked like two respectable Victorians-dark, grim and dull. Though the image ultimately satisfied the Meschers, their experience poses a challenge both to historians' trust in certain kinds of seemingly irrefutable visual evidence, and to the prevailing belief that nineteenthcentury Americans did not have access to, or did not like, color. On the contrary, our past was a colorful place.

3 In our more recent past, events have prompted a reconsideration of some long-held assumptions about the colors of our material history. The controversy over the cleaning of the Sistine Chapel in 1980 posited questions about color to an international audience. In the United States the restoration of Prussian blue and verdigris rooms at George Washington's home Mt. Vernon and revisions to color schemes at the homes of other prominent American Revolutionaries have challenged my countrymen's previously entrenched notions of what constituted respectable colors for colonial American aristocrats. Given the visceral response to these changes some audiences have evinced, one could argue that they have also been perceived by some as challenges to our beloved American forebears' own respectability [Fig. 3 \& 4]. 


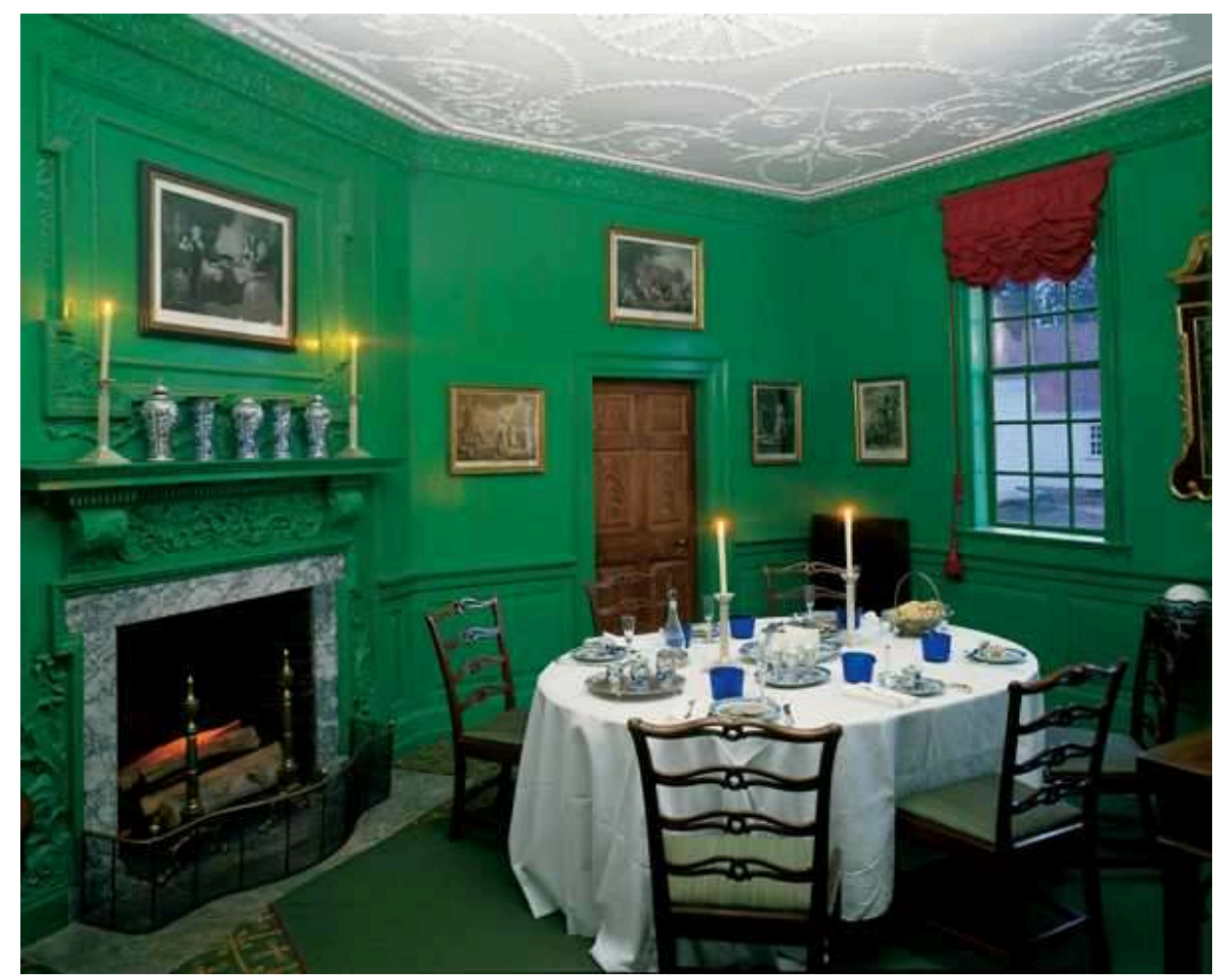

Fig. 3. Small dining room, Mount Vernon, Virginia. Courtesy of the Mount Vernon Ladies' Association.

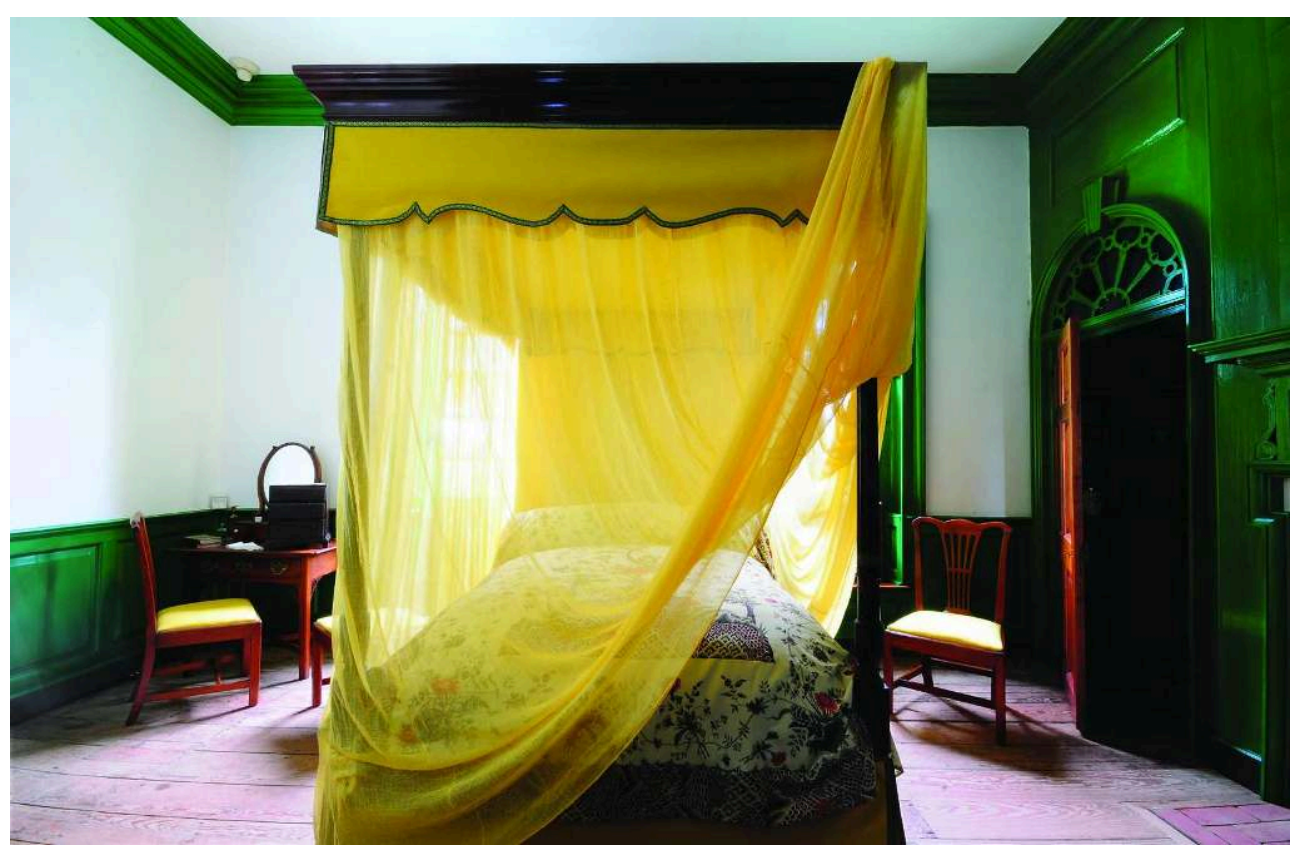

Fig. 4. First floor bedchamber, Gunston Hall, Mason Neck, Virginia. Courtesy of the Board of Regents of Gunston Hall.

4 At Adena [Fig. 5 \& 6], the home of the state of Ohio's first governor Thomas Worthington and a Benjamin Henry Latrobe design, the Ohio Historical Society's dramatic departure from the plain, whitewashed walls of an interpretation that had stood for some fifty years until that point precipitated a reaction so caustic curators felt under siege by an angry public. At the Colonial Williamsburg Foundation one curator described the tone of the response to the restoration of the original vibrant 
colors in the Governor's Palace there in the 1980s as one of "mourning." Docents at some sites have even been discharged over their inability to give tours of the new spaces without evincing their dislike in front of visitors. ${ }^{1}$

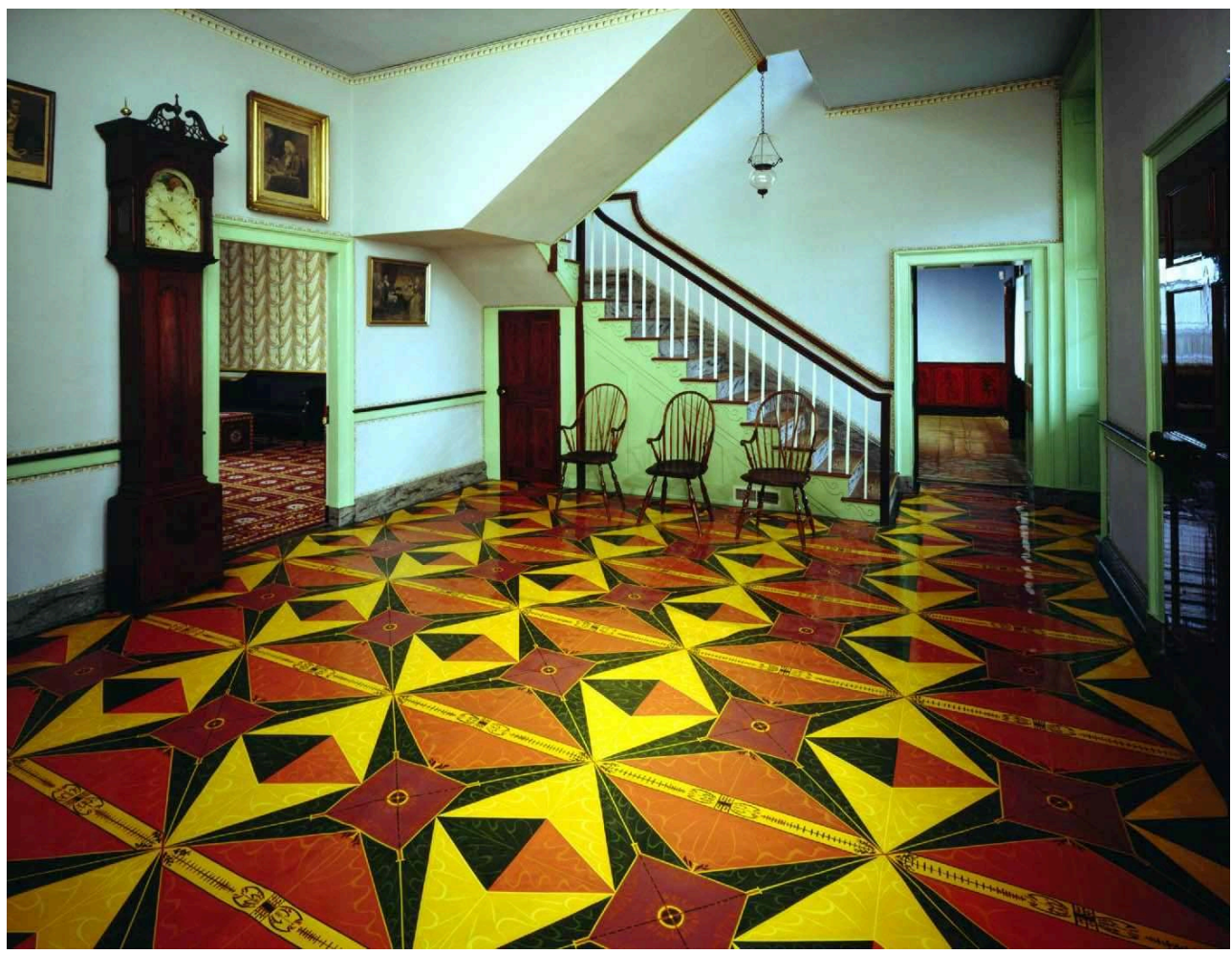

Fig. 5. Foyer, Adena, Chillicothe, Ohio. Courtesy of Ohio Historical Society and Adena Mansion and Gardens Society.

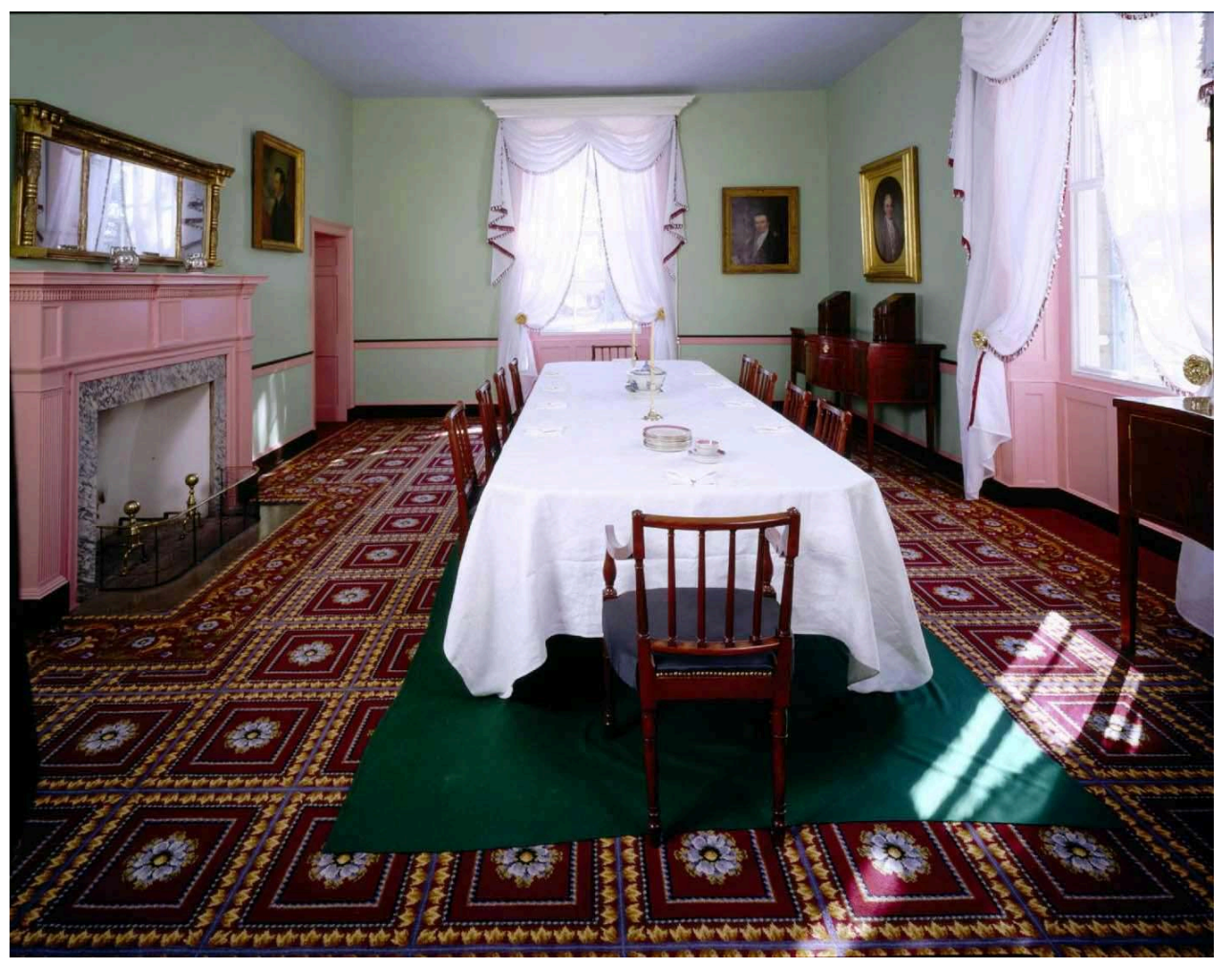

Fig. 6. Dining room, Adena, Chillicothe, Ohio. Original wall colors. The Brussels carpet is a period reproduction. Courtesy of Ohio Historical Society and Adena Mansion and Gardens Society. 


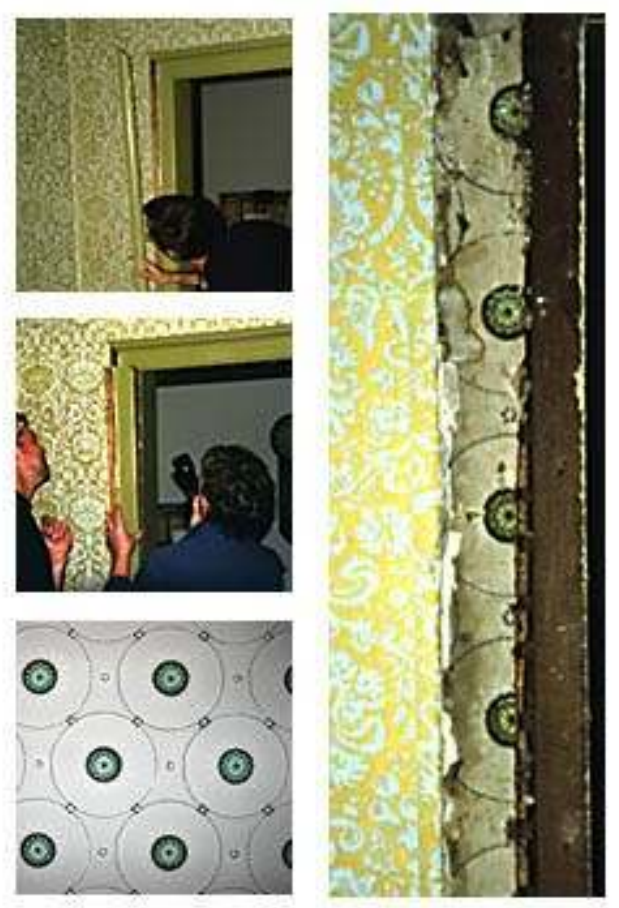

Fig. 7. Pin-dot wallpaper, Library, Adena, Chillicothe, Ohio. Courtesy of Ohio Historical Society and Adena Mansion and Gardens Society.

5 Recognizing that visitors can react badly to dramatic changes in interpretation, particularly changes in color, some sites limit the scope of a revision to specific spaces or furnishing pieces. Shaker historic sites have been among those willing to shake up their visitors with a historically accurate palette. For the last hundred years the idea that the Shakers lived their hard-working, celibate, no-nonsense lives surrounded by simple whitewashed walls and natural varnished woodwork-shunning all things colorful-has become almost an aesthetic paradigm. Recent scholarship has shown, however, that American Shakers celebrated color in their architecture and even liturgy, painting their walls and cabinetry with vibrant blues of varying hues and chrome yellows, greens, oranges and reds [Fig. 8]. Nevertheless, Shaker historic sites daring enough to restore their occupants' original color choices have done so in only a handful of rooms, thereby containing the color and the public reaction to it. ${ }^{2}$ 


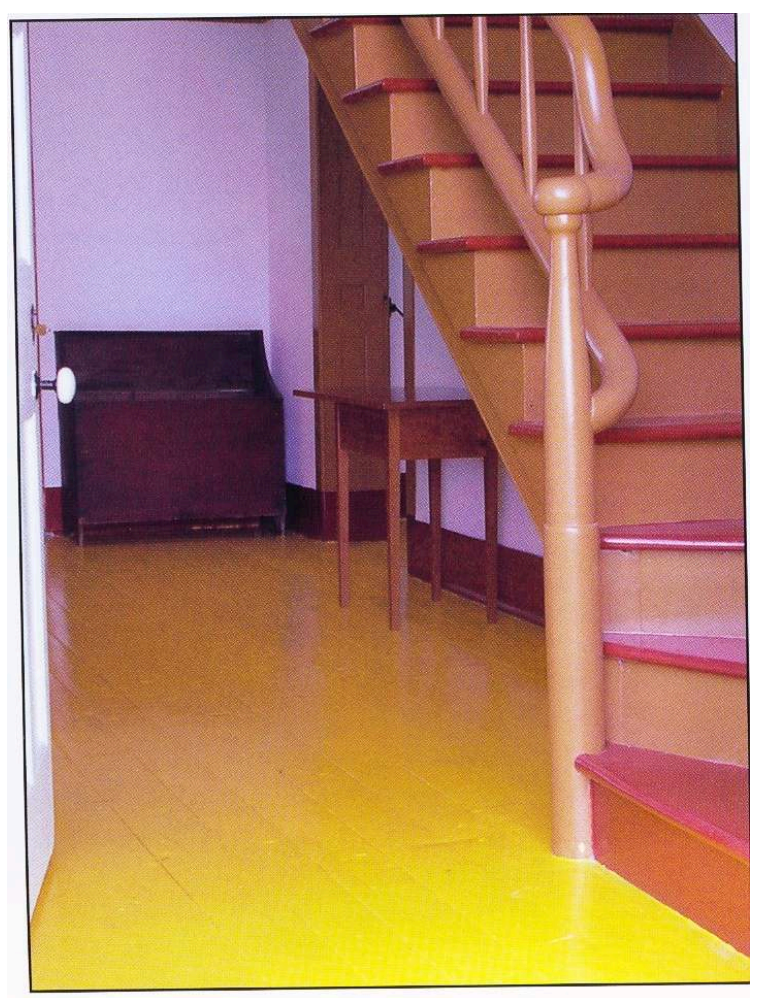

Fig. 8. Hallway, Ministry Office, 1846, South Union Shaker Village, South Union, Kentucky.

Even single pieces of furniture can challenge our collective consciousness of color. Curators at the Shelburne Museum commissioned a finish analysis on their late seventeenth-century Hadley chest, and then applied the results of that study to an exact copy of that chest they had commissioned. Even the conservative interpretation of the data they applied to the reproduction still revealed that in its infancy the chest had looked like this [Fig. 10] which today strikes the viewer more like a piece of Herman Miller furniture or a Mondrian painting than a colonial-era chest. Today museum visitors seeing the chests side-by-side often cannot tell that they are the same, yet in all but color they are identical.

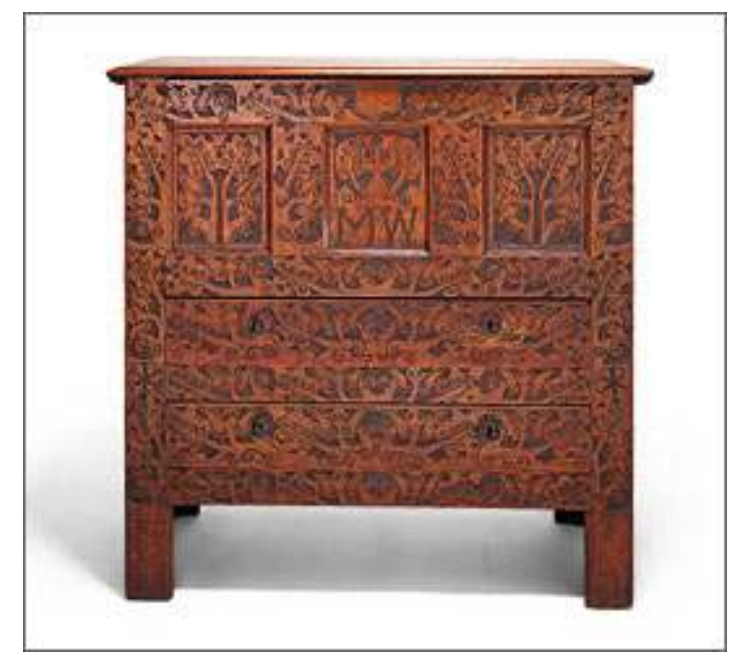

Fig. 9. The collection's original Hadley chest, dating from 1707, Shelburne Museum. 


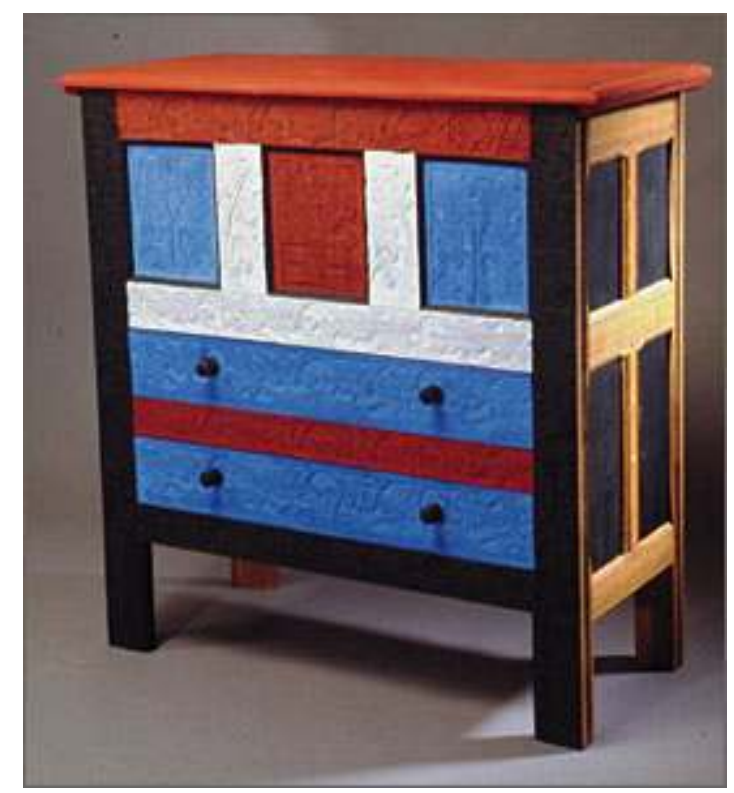

Fig. 10. The reproduction chest with its original colors applied. Shelburne Museum.

7 This is only a handful of examples of some of the notable work that's being done around the United States by historic sites and museums interested in presenting a more accurate depiction of their original occupants' tastes, sites that I use as case studies in my research on the use of color in the American past. My dissertation, Coloring Their World: Americans and Decorative Color in the Nineteenth Century, focuses on the diffusion of color into the everyday lives of Americans living in that time. Specifically, I am interested in the social changes both brought on by, and reflected in, average Americans' application of color to the homespun world around them. The goal of my research is to describe the social historical significance of the color contained in the images, textiles, interior treatments, advertising and decorative arts that Americans sought and valued over the course of the century, with particular emphasis on how the middle and working classes appropriated color in ways formerly available only to elites.

Despite the whiggish notion of American self-sufficiency that developed early in the nineteenth century, before 1800 Americans had to turn to Great Britain or France for luxury goods-finely finished clothing and furnishing fabrics, ceramics, wallpapers, pigments and colorants among them. Wealthy Americans could afford to cover their walls and furniture with expensive pigments and labor-intensive painting techniques, and dye their silks, velvets and fine woolens with rich colors produced by rare dyestuffs. Though late eighteenth-century Americans displayed a high level of literacy, fluency in visual culture-for instance, being able to see and understand certain markers of social distinction-was still critical to navigating in their society. Slaves, for instance, were sometimes prohibited from wearing the master's hand-me-down clothes in a way that supposedly mixed their colors inappropriately. ${ }^{3}$ However, in general, sumptuary laws had never held sway in the colonies, and by the time of the American Revolution were all but gone. It was cost, more than anything, that proscribed the general public's access to color.

9 American elites knew the importance of surrounding themselves with the trappings of luxury, using visible signs of social and economic status. Color was one of those 
trappings. In the colonial and Federal periods they ordered fancy painted coaches and boldly colored liveries from Europe, and painted their walls with dazzling glossy finishes like verdigris and deep Prussian blue, an expensive synthetic colorant. Like his contemporaries, George Washington greatly concerned himself with color, both its fastness and its fashionableness, and made socially and politically motivated color choices. When he ordered a new coach in 1768 he wrote to his London factor the following preferences and caveats:

One of this kind therefore woud be my choice; and Green being a colour little apt, as I apprehend to fade, and grateful to the Eye, I woud give it the preference, unless any other colour more in vogue and equally lasting is entitled to precedency, in that case I woud be governed by fashion.

10 He approved other ornaments "together with my Arms agreeable to the Impression here sent" and some light gilding, unless they would give the carriage a "tawdry" look. ${ }^{4}$ Purchase orders to overseas agents from American elites frequently referenced copying the colors of items previously manufactured for their neighbors.

Color's allure did not diminish in the nineteenth century, and from the beginning of that time a number of forces combined to make it more accessible. From the unassuming little dyer's manuals of the first decades of the 1800s that divulged an ancient guild's secret formulas to home practitioners, to the chromolithographed trade cards that were given away free to anyone at century's end, the nineteenth century experienced a democratization of color.

12 Several technological advances made the mass distribution of color possible. Improved roads allowed blue-bodied Conestoga wagons, yellow stage wagons and vari-colored sleighs and sledges to pass West; canal boats and the steam ships that plied eastern American rivers bore the colorful calicos rolling off English and American mills to families living in the interior of the country. Together the processes of printing from engraved copper rollers instead of plates or blocks and producing paper on continuous rolls revolutionized both the textile and wallpaper industries, reducing costs as these products moved from hand to machine production and greater economies of scale. At midcentury, the creation of synthetic dyes permitted even working-class people to afford vibrantly colored fabrics, while upper middle-class women brightened their beds with quilts appliquéd first with delicately colored chintz, and then with primary yellows and reds, and vivid greens. Working-class women made it possible for middleclass women to color their world. Godey's Ladies Book and firms like Currier and Ives hired women colorists to hand tint the fashion pages of their magazine and color their art prints respectively; and in the latter half of the century the domestic art pottery field employed women to decorate ceramics designed to appeal to the bourgeois tastes of their customers. By the middle of the century many Americans could afford to paste their walls with mass-produced, exuberantly hued wallpapers, whose complex arrangements let humble parlors to mimic the lush interiors of aristocratic homes. The invention of chromolithography allowed art and periodical printers, book publishers, advertisers, and manufacturers to industrialize and embellish printing with lush color, making color available to virtually everyone. Americans even collected color; auction tables today invariably hold a Victorian scrapbook or two filled with chromolithographed trade cards and advertisements, which companies produced to capitalize on the public demand for color. 
13 At the turn of the nineteenth century, color moved quickly to the American frontier, a process facilitated by the technological and transportation developments of the Market Revolution. The most colorful furniture in the country came from Baltimore, Maryland and Lancaster County, Pennsylvania, where in the early nineteenth century it was discovered that the ground was littered with chromium, nondescript black rocks whose compounds create vivid greens, yellows, oranges, and reds. The first federal mail carriages-bright green coach bodies trimmed in vermillion, black, and patent yellowdelivered tiny packets of dyestuffs like logwood and cochineal from Central America, and indigo from the Lowcountry of Georgia to dry goods stores in the American interior. There these exotic materials joined locally harvested products-like blood, urine, galls, nutshells, and dung-to produce the beautiful but often unpredictable and ephemeral shades of the antique dyes. In the first days of the Republic, authors of American dye manuals revealed the centuries'-old secrets of dye "chymistry" (sic), long protected in Europe by one of the last surviving guilds, at the same time that they argued for the importance of establishing a domestic dyeing industry. In this way, they claimed, Americans might "enrich" themselves as a nation both aesthetically and economically, and "private families" might "colour their own yarn of woolen, worsted and thread [...] to have clothes as beautiful as the wealthiest American." ${ }^{5}$

The first decades of the nineteenth century saw the invention of the Jacquard loom that allowed weavers to create strikingly graphic coverlets for people of modest means even in rural places. Itinerant limners traveling with their own colors painted trade signs and vehicles, and brushed, stenciled, grained and stamped color onto house interiors and exteriors. In this era a patrician Adams palette coexisted with kaleidoscopic "Fancy Goods," and a burgeoning domestic textile industry in the American northeast began to cut in on Britain's calico business.

In the latter half of the century important by-products of the Industrial Revolution brought even more color into Americans' lives. The bureaucratization and calls for efficiency that came to characterize modern business operations after the American Civil War seeped into the ever more colorful middle-class home, just as they affected how color was both manufactured and distributed. Instead of being laboriously ground on site, paint could now be factory made, dispensed in cans, and shipped on rails. The process of transfer printing allowed Americans to dine from industrialized china that looked hand-painted in blues, greens, reds, browns, and purples but at a much reduced cost. Surrounded by papered walls covered in hand-colored prints and samplers, midcentury Victorians perched on their stiff, overstuffed parlor furniture tufted in deep red, black and green damasks, mohairs, and velvets, as they gazed down at their largepatterned, often meretricious, carpets. Middle-class homes at the middle of the century were now where architects and publishers directed their efforts, where the stylistic influences of Romanticism, Naturalism, and Orientalism began to converge with the designs and palettes of Andrew Jackson Downing [see below], Alexander Davis and their contemporaries.

16 At the beginning of this period the prospect of owning several colorful objects was finally real, but was new enough that Americans had difficulty implementing color in their spaces in a socially acceptable way. As they furnished the home they had just completed in 1842 in Ross County, Ohio, landowner William Dunn wrote to his brother to take care to buy a "superfine ingrain" carpet, "something just between a light carpet and a dark one but still one with very little white in it. One whose light colouredness 
was made up more by the other light colours than by white." Recognizing that he himself was well-off but with only a humble country patronage network, Mr. Dunn was afraid of alienating his poorer neighbors by creating too "shewy" a décor of deep colors. Americans' unfamiliarity with their newfound access to color made them tentative at times about how they would use it. But they wanted it nonetheless. ${ }^{6}$

The new arbiters of fashion moved quickly to fill Americans' educational void. It was after 1840 that the simple little housekeeping manuals of the first part of the century evolved into encyclopedic tomes on every aspect of domesticity, including guiding their readers in the respectable use of decorative color. Authors like Catherine Beecher even went so far as to tell her readers precisely what lithographed images they might hang on their parlor walls. Advocates for a new American architecture like Andrew Jackson Downing and Calvert Vaux poised themselves to satisfy the "inexhaustible demand for rural residences" in the country. "Meagre, unartistic buildings" would have to give way to a higher level of design, of which color was an important component. In Vaux's view republicanism had retarded Americans' aesthetic development; the "democratic element" had rebelled against the fine arts as manifestations of "pomps and vanities so closely connected with superstition, popery, or aristocracy," and in doing so had sacrificed their artistic development to their progress in "commercial prosperity and political importance."7

Ironically the means of financing their new homes came precisely from their commercial prosperity, and industrialization in the form of steam-powered, machinemilled lumber and factory-made paints made ornamenting these rural dream homes affordable. The new "industrious classes" were now empowered to "decide the national standard of architectural taste," and "the spirit instilled in their designs" needed to reflect their unique American idiom. ${ }^{8}$ In the end the derivative designs coming from Downing et al. celebrated European antecedents-the Tuscan villa, Swiss chalet, and Norman castle-but now tweaked for their new milieu. European eclecticism crossed with American exceptionalism hybridized the American Cottage Ornée, a housing style brimming with color and ornament inside and out. Though American architectural critics endorsed the style, they worried about putting even vernacular design into the hands of an unschooled middle class with lots of capital but no better than a "cockney" grasp of color. In embracing the unrepentant asymmetry of the Picturesque, Downing, Vaux and their contemporaries denigrated not only the blocky form, but the glaring white of the Greek Revival, Americans' most "republican" style. And even as these transplanted Greek temples with white marble facades went the way of their ancient forebears, Downing and his peers still decried their countrymen's habit of "Vitruvianizing" public buildings, and fretted over homeowners who rejected the decorous obscurity of country life by painting their homes a blinding white:

If you or any man of taste wish to have a fit of the blues let him come to the village of -. I have just settled here; and all my ideas of rural beauty have been put to flight by what I see around me every day [...] new wooden houses, distressingly lean in their proportions, chalky white in their clapboards, and spinach green in their blinds. There is not a tree in the streets; and if it were not for fields of refreshing verdure that surround the place, I should have the ophthalmia as well as the bluedevils. ${ }^{9}$ 


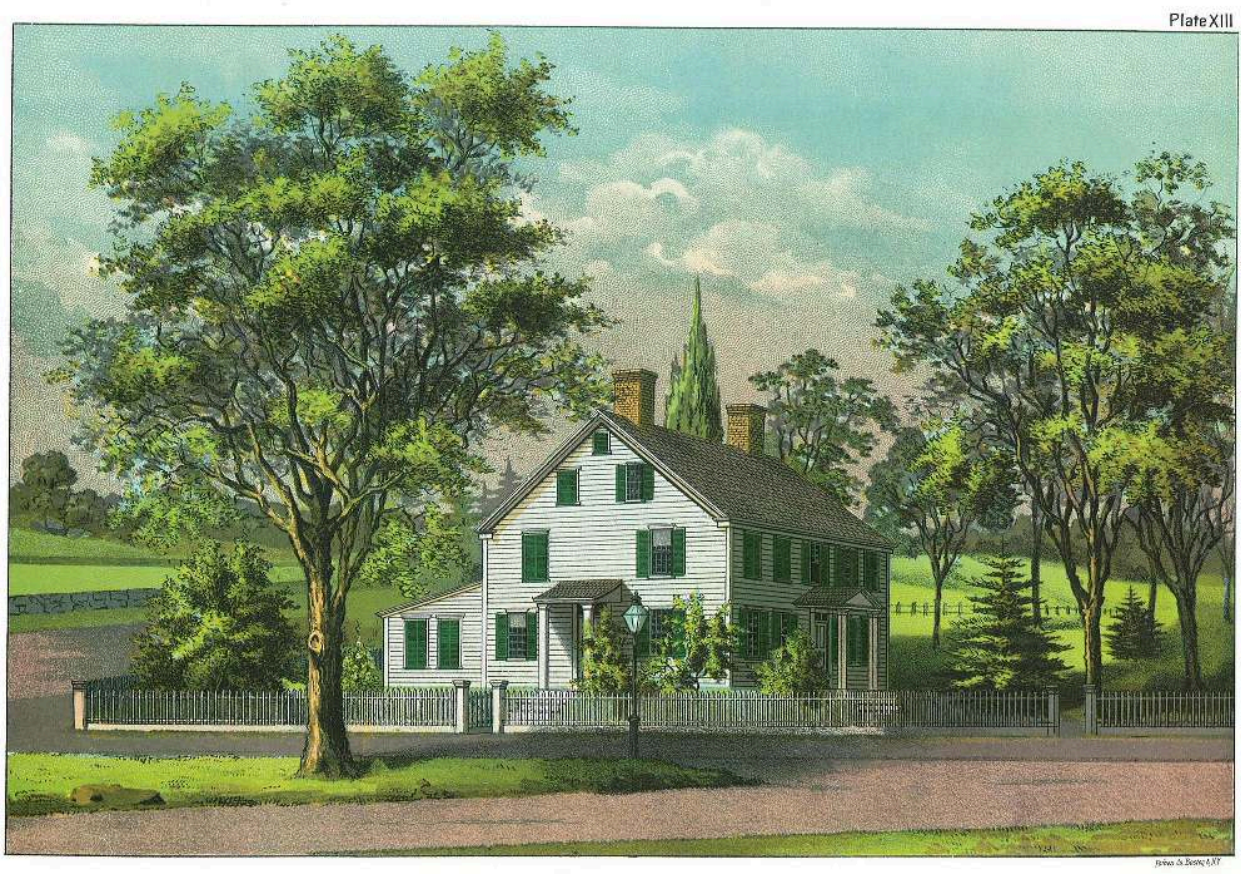

Fig. 11. Chromolithographed plate, from a paint manufacturer's catalogue of 1885. Athenaeum of Philadelphia.

19 Just as prescriptive in their recommendations for finish as they were of form, the authors of architecture manuals now detailed the use of color, often including guidelines for interior decorations. In their books both Henry Cleaveland and Sloan allowed for the use of "cheerful" colors inside and out, but unlike Downing and Vaux they vehemently denounced adding tints to faux finish one material to look like another-clapboard for stone, oak for mahogany, for instance. Most of this period chose a more neutral palette for their exteriors. Downing adamantly endorsed colors from nature more sympathetic with the rural landscape for house body exteriorsbrowns, putties, greys, and mild yellows, for instance. Samuel sloan thought Acadia stone from Nova Scotia to be of the most agreeable tint for villas, especially contrasted with the emerald of the lawn, but found domestic lime stones to be too white for most applications. But for trim these designers were willing to range wildly over the color chart, encouraging the liberal use of multi-colored slate roof tiles, soffits and ornate steam-milled lumber that contrasted with body and trim colors, vergeboard, awnings, bays and window frames painted in bright colors picked out in even brighter colors. 


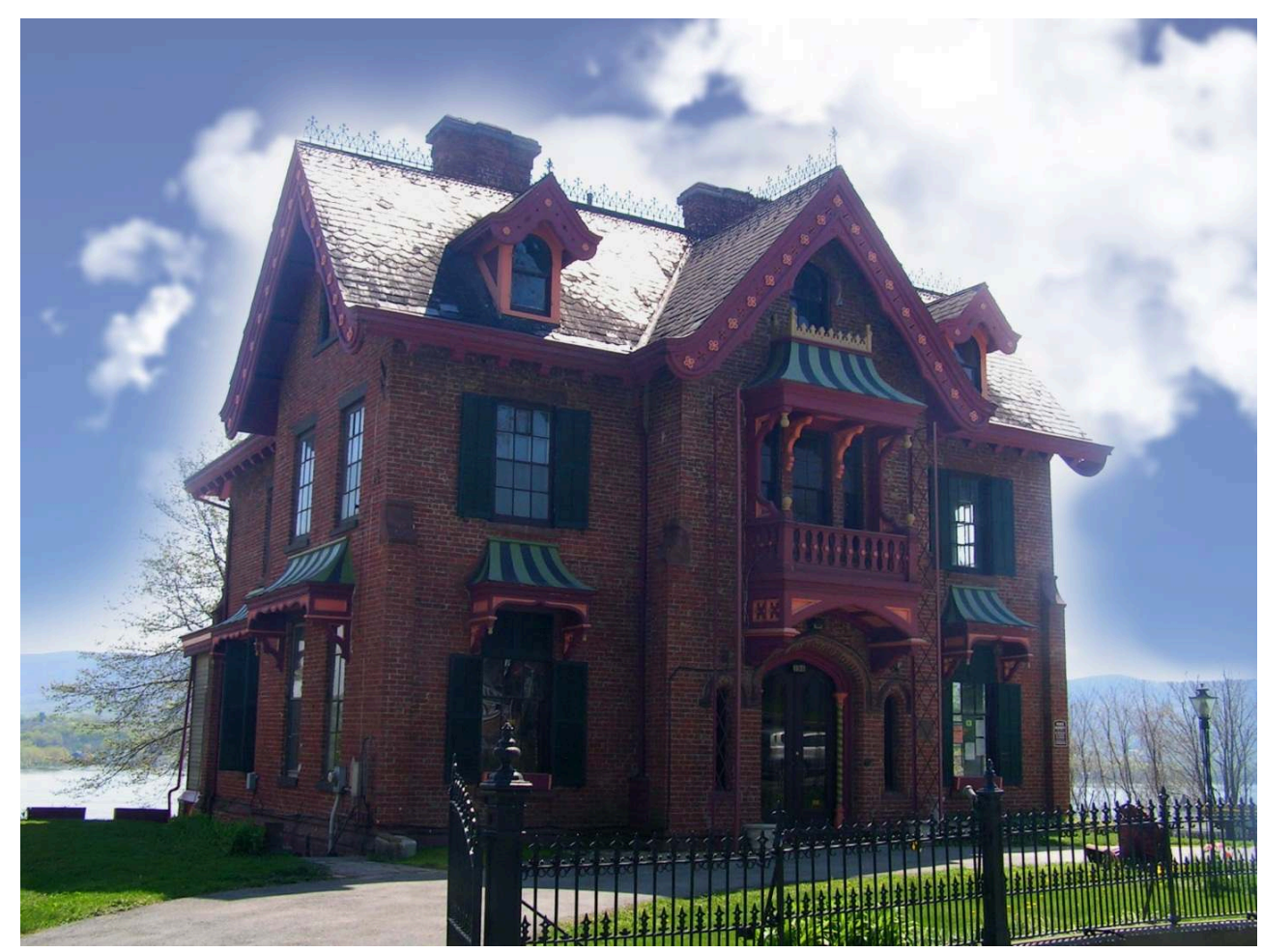

Fig. 12. Known as the Warren House, this villa designed by Calvert Vaux sits along the Hudson River in Newburgh, New York.

Filling those frames more and more were stained-glass windows, as technological innovations had recently brought their cost within the means of the middle class. All of these visual effects combined to create the "gingerbread" look by which we still recognize these styles. Just as adamant about the grounds as the house, building manuals insisted on the importance of surrounding each home with an emerald sea of lawn, multi-colored gravel paths, trees of variegated foliage, and flowers arranged by color, or as Downing described it, the painterly effect of "masses of crimson and white, of yellow and purple, and the other colors and shades, brought boldly into contrast, or disposed so as to form an agreeable harmony." 10

21 In 1851 Downing complained about American steamers and luxury hotels filled with velvet upholstery and "purple and fine linen," fripperies he found to be just as antithetical to a respectable republican existence as bad national architecture. ${ }^{11}$ But Downing chose a poor time to complain about purple. The color was about to explode in popularity. In 1856 an American factory rolled out a flashy purple Rockaway carriage, and in upstate New York the Reverend Levi Hill first brought colors, including an iridescent purple, to the photographic process he invented in the little shed behind his house. In Great Britain Owen Jones published the treatise that would demonstrate to the world the aesthetic possibilities of both the chromolithographic process and exotic ornament, and in the same country an 18-year-old chemistry student named Perkin invented the purple dye that began unlocking the secrets of organic chemistry, ultimately ensuring that any color could be applied to any medium. If mid-nineteenthcentury Americans were living in a time of seismic shift where color was concerned, 1856 was its fault line. ${ }^{12}$ 


\section{No. 94.-Mauve.}

In a soap bath add a little acetic acid, and dissolved aniline to shade. $1 \mathrm{~B}$. was used for this pattern; for bluer shades use 4 to $6 \mathrm{~B}$.

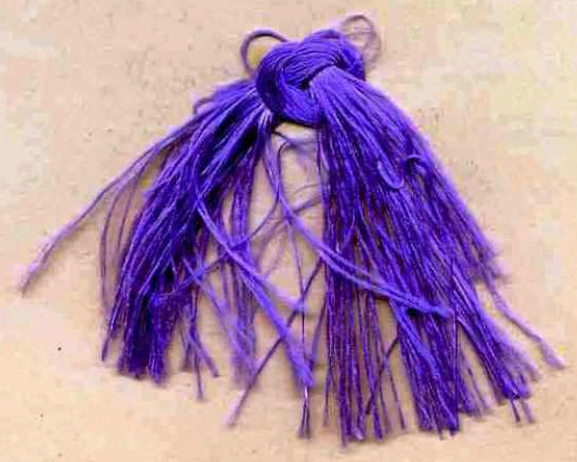

Fig. 13. Swatch from a professional dye manual, Thomas Gibson's American Practical Dyer's Companion of 1878,56 . Courtesy of the Smithsonian Institution Libraries.

Mauve, or mauvine, was the first of the coal-tar, or aniline, colors synthesized from the by-products of a newly steam-powered, industrialized world. ${ }^{13}$ The sensation that mauve caused spurred the invention of hundreds of other colors within a short span of years, including magenta, fuchsia, and electric purples and blues.

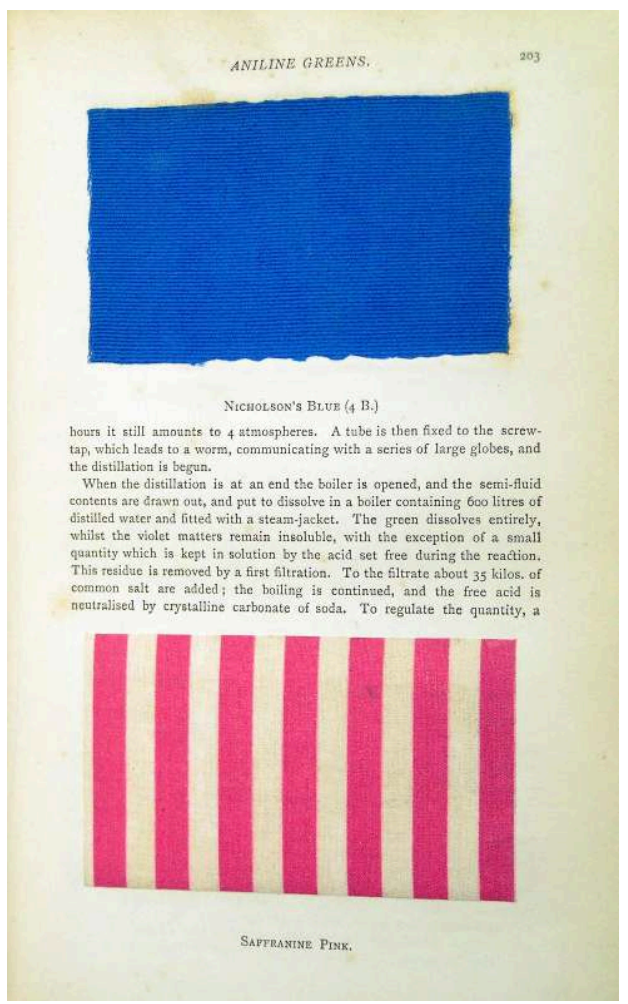

Fig. 14. Two of the hundreds of aniline-based colors produced by laboratories in England, Germany, and France in the years after mauve's discovery. Illustrated in William Crookes, A Practical Handbook of Dyeing and Calico-Printing, London, Longmans, Green, and Co., 1874. 
It was the demystifying of the chemistry used in creating these colors that quickly moved the locus of debate between theoretical and applied science to color. The victory of applied sciences is reflected in the very short gestation of the modern pharmaceutical industry birthed shortly after. It was a period of lightning-fast transition: dunged and oiled vegetable-based Turkey reds, still based on an ancient recipe, comfortably cohabited with lab-produced aniline greens on the creamy white surfaces of several quilt styles popular in the era [Fig. 15 \& 16].

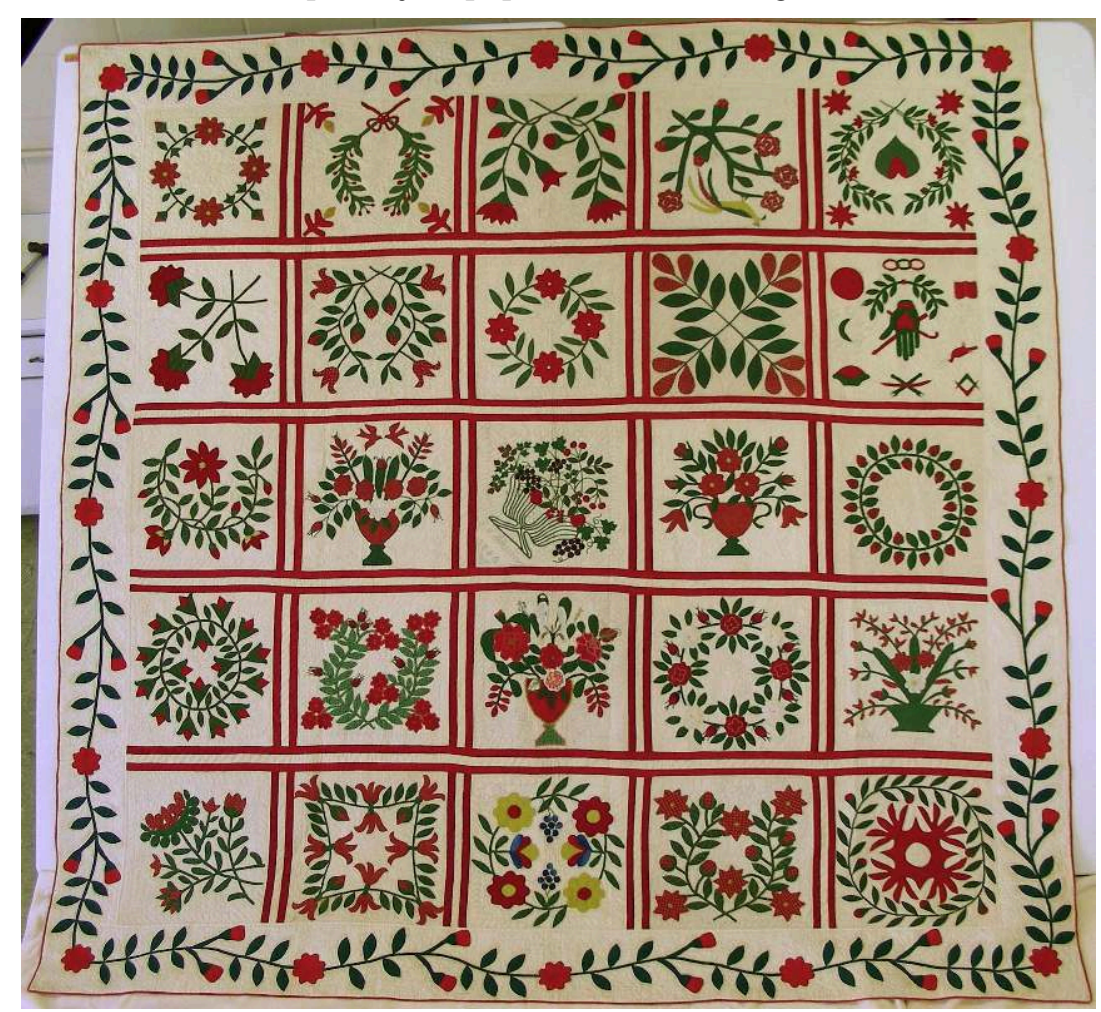

Fig. 15. Appliqué quilt, Baltimore album style, 1854. Private collection.

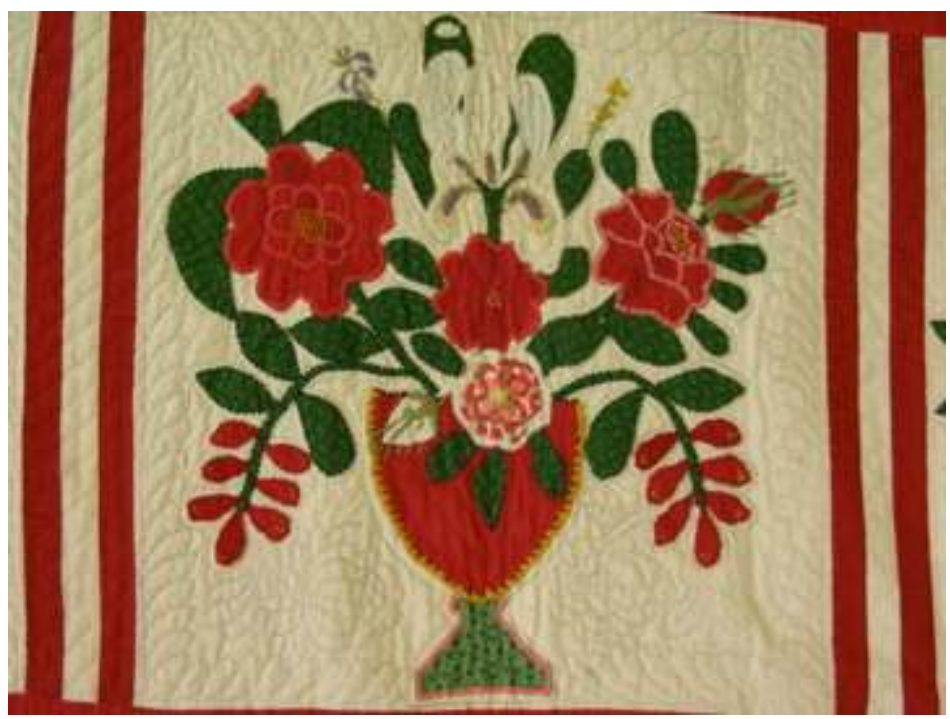

Fig. 16. Detail of a heavily embroidered central block.

24 The invention of artificial alizarin at the end of this period signaled the end of naturally cultivated reds. In fact, the success of the aniline colors sealed the fate of all colors, 
which by the end of the century would come almost primarily from the factory, no longer from the field.

After 1870, the visual complexity of Americans' surroundings increased, both inside and outside their homes. This period saw the proliferation of saturated, often more somber colors across the popular palette in paint, textiles, ceramics and furnishings. Color also seeped into American literature in the form of literary impressionism, and appeared fractured and crazed on the surface of late nineteenth-century America's favorite quilt style.

26 Far from crazy, the construction of a well rendered crazy quilt [Fig. 17], like the other optically dazzling quilts of the period, required planning and access to myriad textile samples in a wide variety of colors and textures. Such complex quilts became possible only as American textile mills churned out the diversity of fabrics and colors required to create the quilt's stained-glass appearance, and enough women found the leisure to embellish each shard of color with the contrasting fancy embroidery required of a wellexecuted crazy quilt.

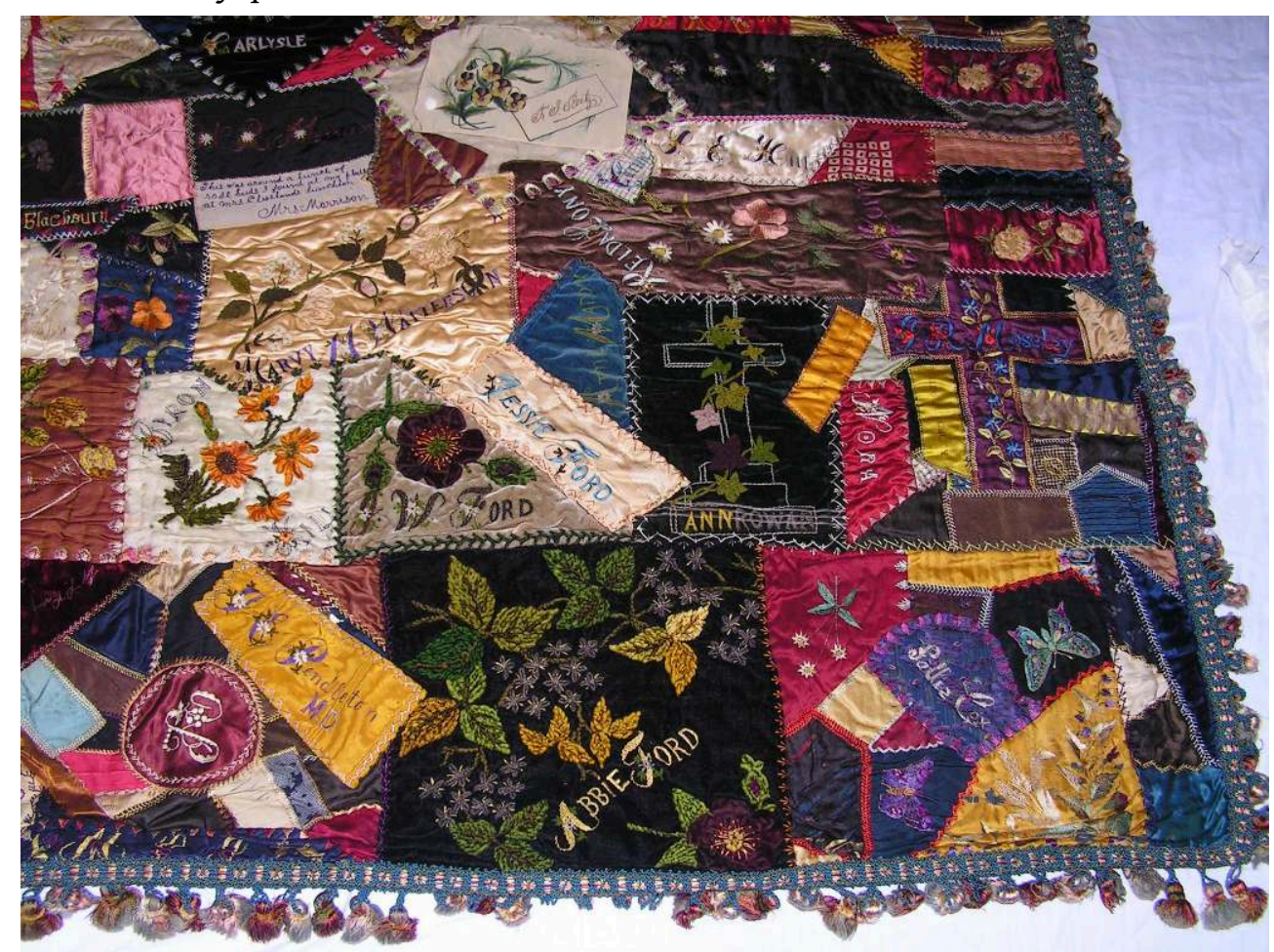

Fig. 17. High-style crazy quilt, 1886 by Maggie Williams. Kentucky Museum and Library.

Many Americans now acquired their fabrics at the huge new department stores that had replaced the dry goods merchant all over the North, a phenomenon that fostered the accumulated display resulting in an aesthetic style known derogatorily as horror vacui. It was this overt materialism based on mass production that invited the criticism of contemporaries like Thorstein Veblen and William Morris. But Americans of this period were hardly Philistines; in fact they displayed a collective obsession with the "artistic." Everyone from architects to aesthetic theorists to magazine publishers to toilet manufacturers was telling them that household efficiency wasn't enough-that household artistry was essential to the social and even political development of the country. Correctly manipulating the new grammar of color now underlay the artistic. In 1879, for instance, author Julia McNair Wright wrote five pounds or so of a 
household advice manual-The Complete Home-which counseled its middle-class readers through the insufferably pedantic character of Aunt Sophronia, a sort of nineteenth-century Martha Stewart who never hesitated to tell her readers just why they had bad taste. For Aunt Sophronia, good housekeeping required more than efficiency, it required artistic decorating. She specified how colors should be used in each room of the house, in decorative arts, and in clothing. She tailored her advice to the socio-economic classes of her readers: where the mistress might have to insist on expensive red velvet, the servant might effect a similar impression with cheaper red calico. Sophronia's bossy, unsolicited voice was only one of hundreds echoing the new principles of good taste from a vast corpus of similar literature written since midcentury, all premised on the tenuous notion that a beautiful home, and in this latter period an "artistic" home, made for a better America. Manufacturers took the same tack in their marketing, advertising certain colorways and patterns to specific consumer classes. Apparently Americans listened. Photographs of domestic spaces from the late nineteenth century show a remarkable conformity to this new aesthetic.

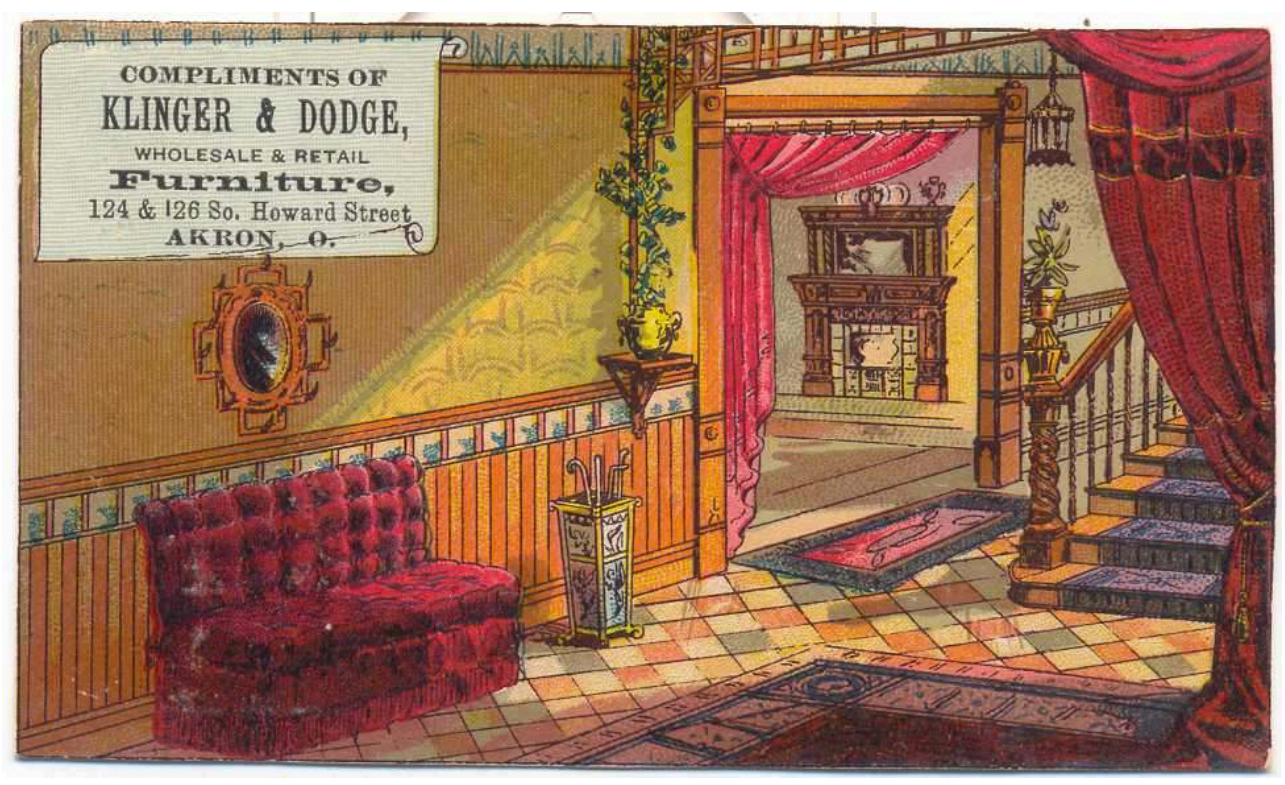




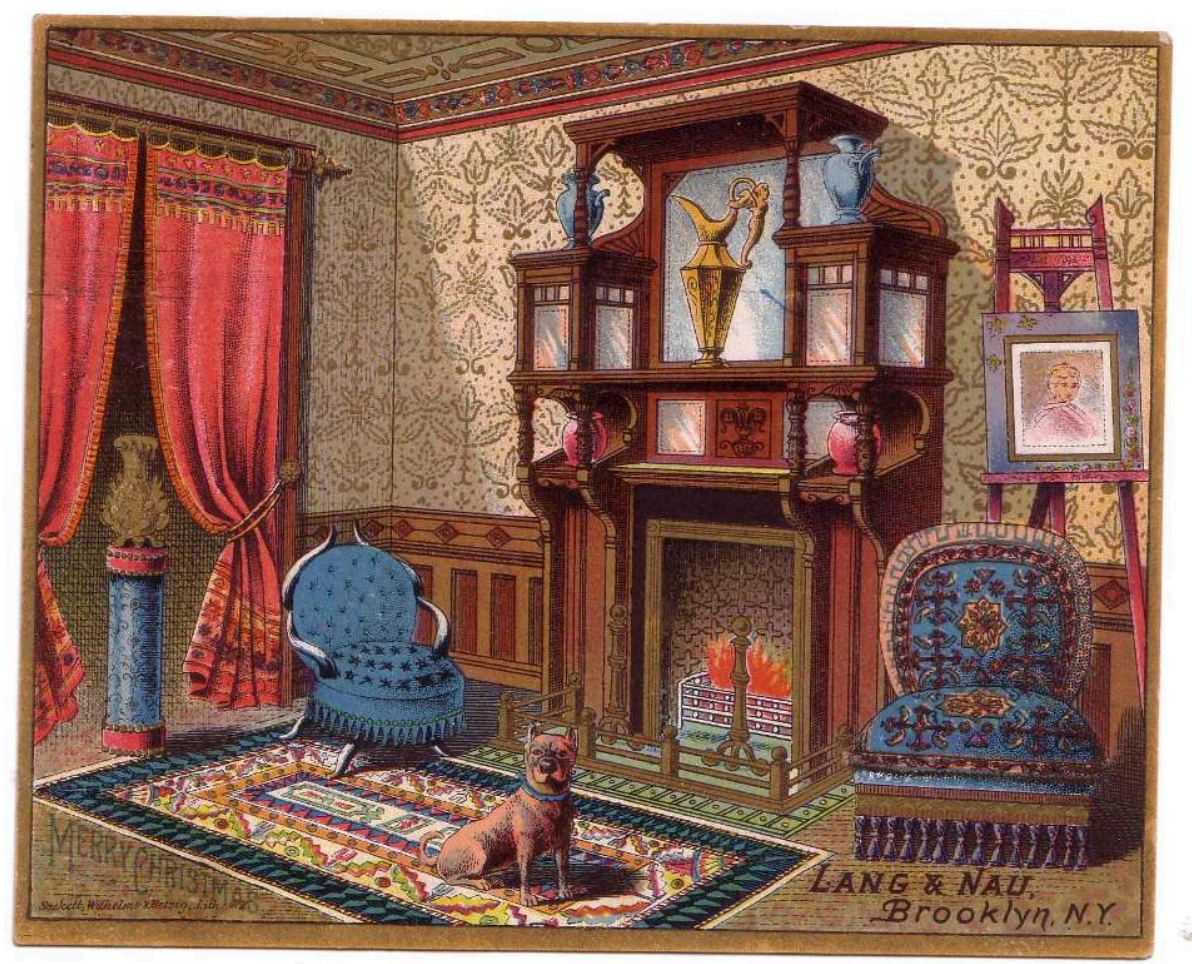

Fig. 18 \& 19. Chromolithographed trade cards produced by furniture companies in the 1880 s, found in late $19^{\text {th }}$-century scrapbooks. Private collection.

28 While at mid-century "fine-art" chromolithographs had graced the walls of middleclass parlors whose owners aspired to refinement, chromolithography-dubbed "the democratic art" by one commentator-did not hit its peak exposure until later in the century in the form of commercial ephemera. Exhibitors at Philadelphia's Centennial Exhibition in 1876 launched the trade cards that became so popular with advertisers and consumers until the end of the century. These cards are so loaded with social content it is a shame scholars have virtually ignored them [Fig. 18 \& 19]. 


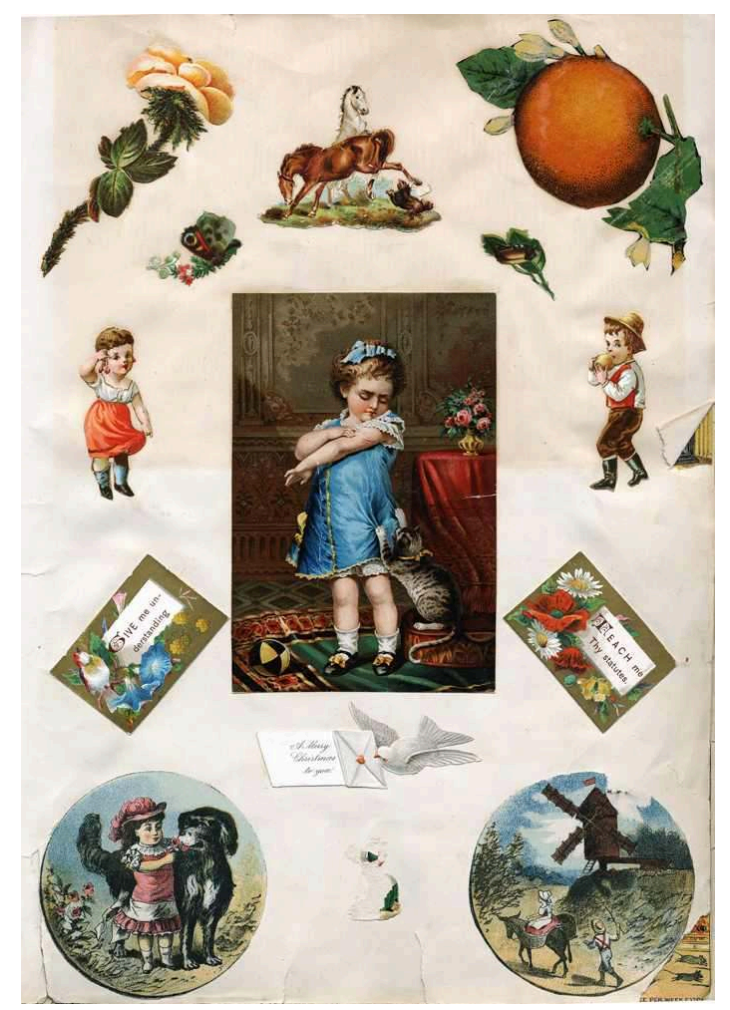

Fig. 20. A page from a mid-ninetenth-century scrapbook. Private collection.

Taking advantage of this colorful new print medium, paint manufacturers began publishing their suggestions for house treatments in chromolithographed folios and trade cards, some with paint chips included [Fig. 20]. It is hard to exaggerate just how elaborate their recommended color schemes were, where each decorative elementstringcourses, fenestration, doors, bays, porches, roofs, etc.-might be coated in a unique color. Those colors were now drawn from a new palette of more subdued yet saturated mature tints. 

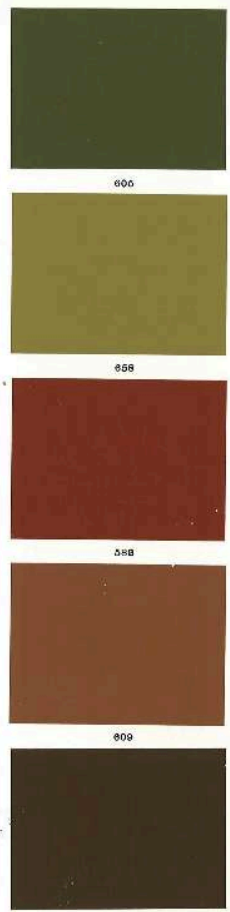
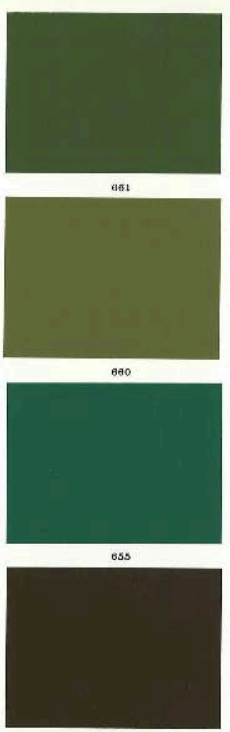

657

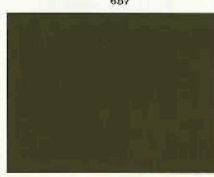

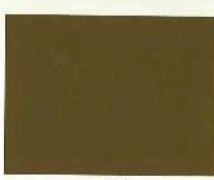

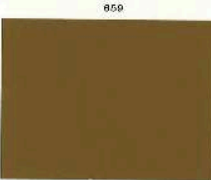

sas
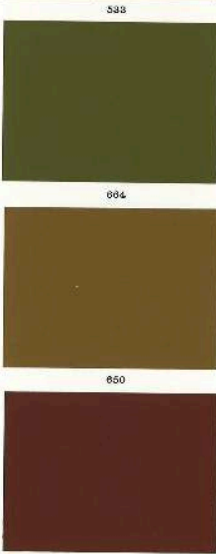

$\frac{587}{94}$

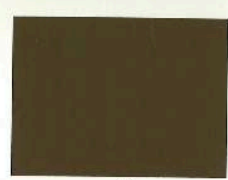

a54
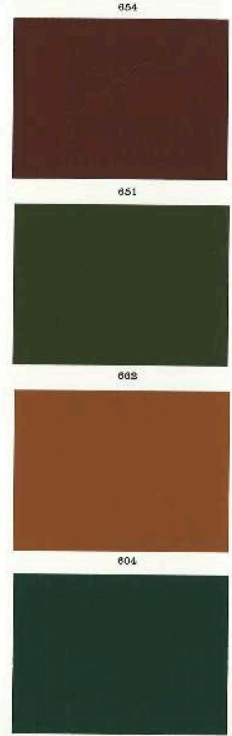

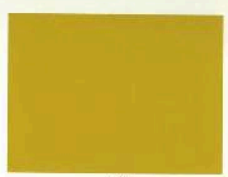

sso
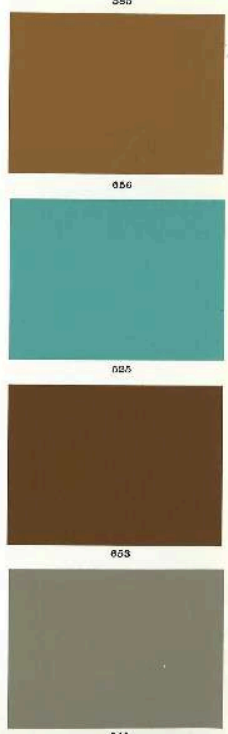

Fig. 21. Portfolio of Modern House Painting Designs, produced by John Lucas \& Co. in 1887. Athenaeum of Philadelphia.

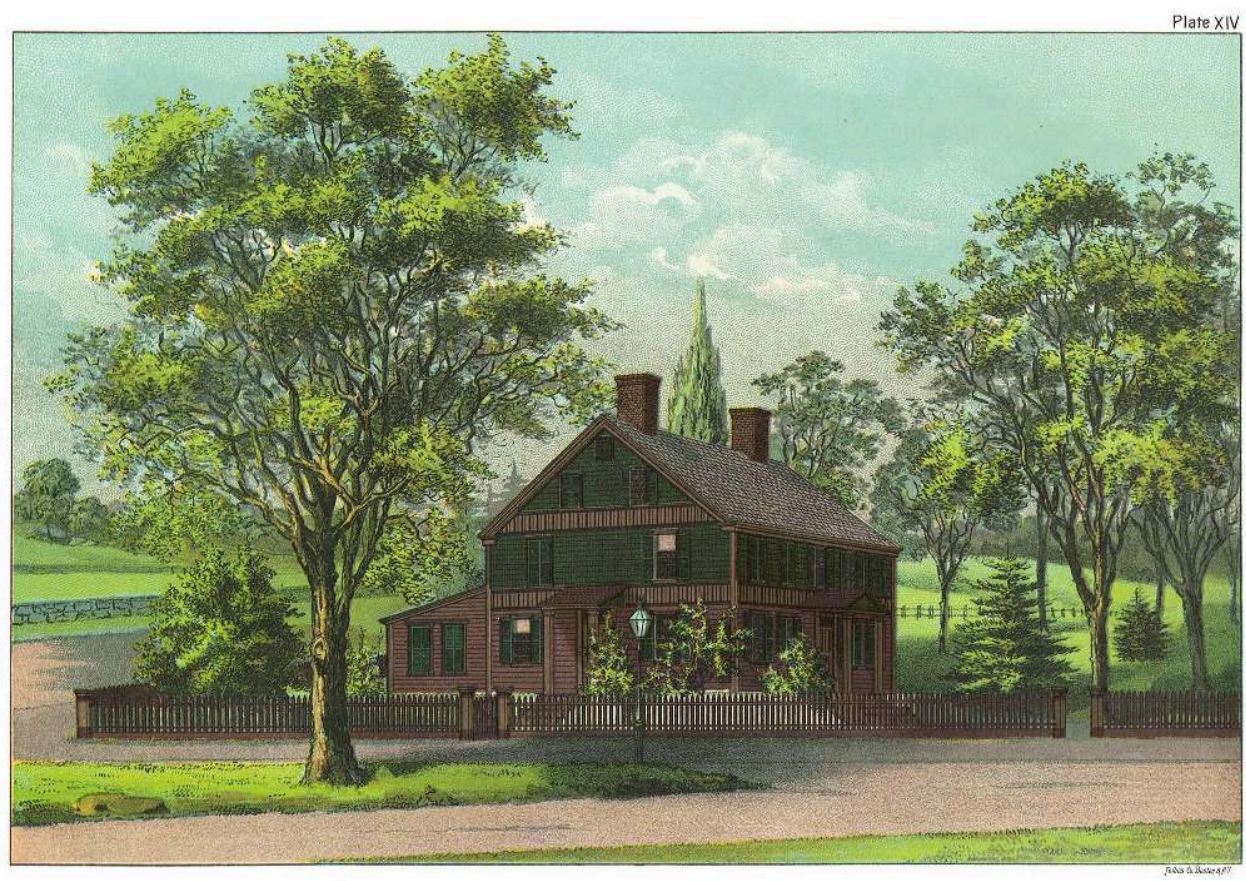

Fig. 22. The same house illustrated in Fig. 11 but with one of the color schemes recommended to the consuming public in the 1880s by a paint manufacturer. Athenaeum of Philadelphia.

30 After 1893 Americans swept away the late Victorians' dusty portieres and germ-hiding dark palette, bringing color under control in what might be described as a national "whitening". In 1893 the White City of the World's Columbian Exposition suggested to an international audience that civilized spaces were meant to be white and the 
Supreme Court's reaffirmation of racial segregation in the country three years later corroborated the point. This cultural whitewashing continued throughout the decade and beyond, as America's White Fleet plied the waters to colonize "dark" places, textile manufacturers introduced a new pastel palette, and a new class of social commentators, professional decorators, and colonial revivalists stripped and sanitized domestic spaces.

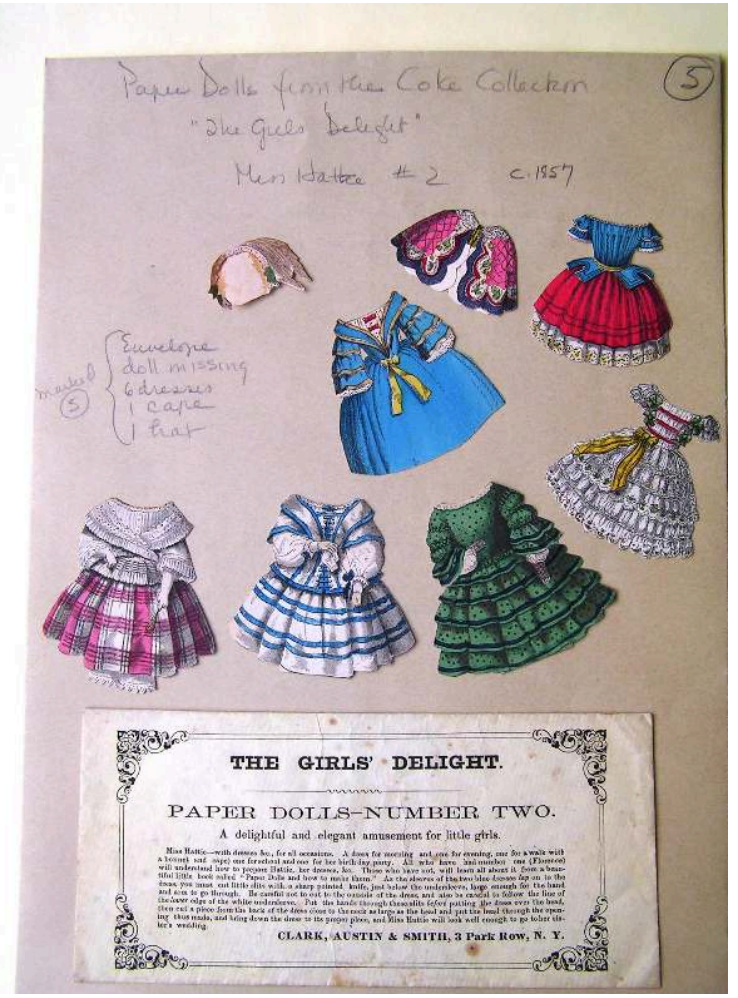

Fig. 23. Paper dolls produced by a toy manufacturer in the 1850s, showing the bright textile palette of the period. Kentucky Museum and Library. 


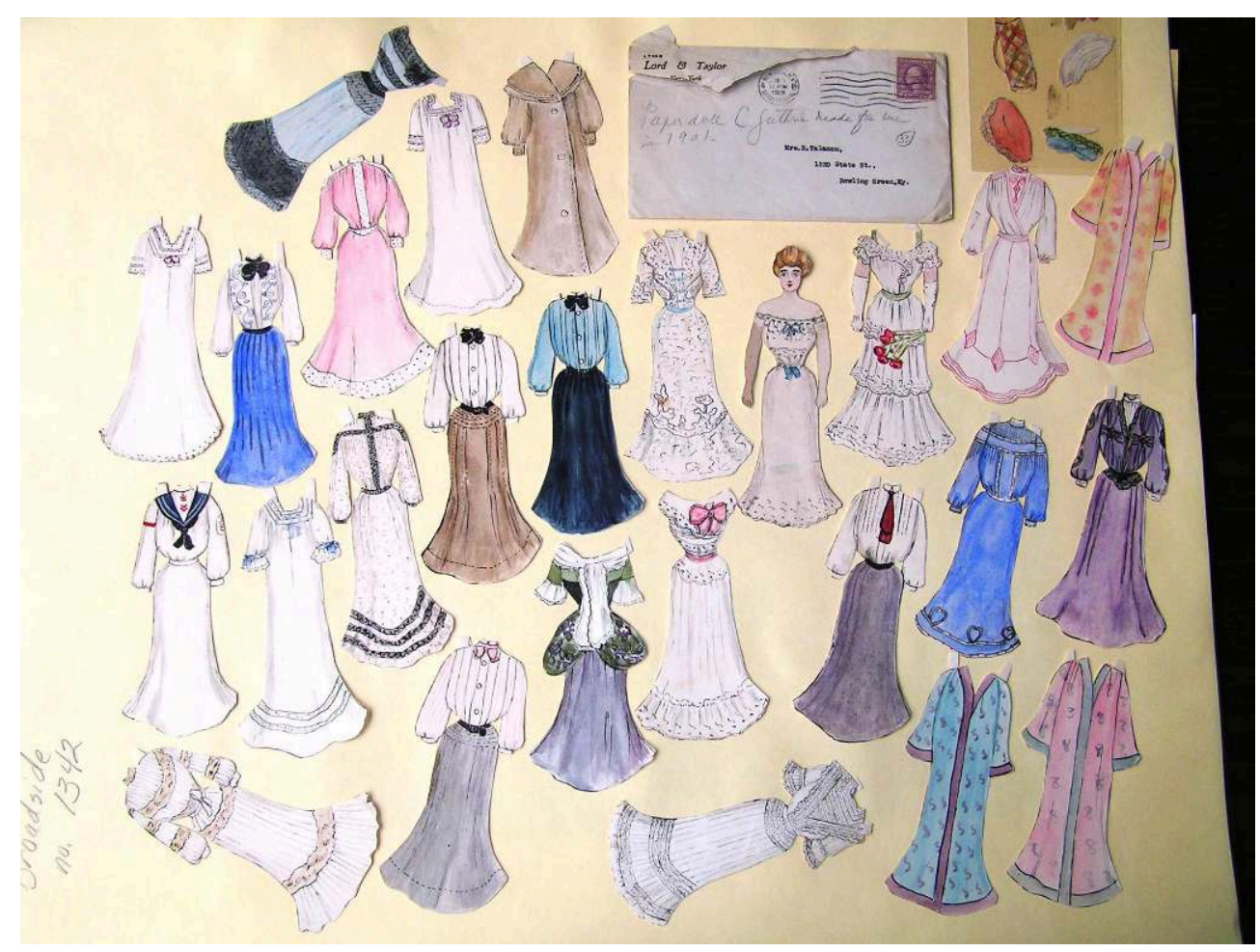

Fig. 24. Homemade paper dolls of the turn of the twentieth century illustrate the dramatically lightened costume palette after the mid 1890s. Kentucky Museum and Library.

It was at this time that colors were first standardized, and color theory became a component of public education curricula. According to the decorators-turned-social critics of this period control of decorative color belonged to "born colorists who spoke its "natural language"' and could decipher its laws based on observation and study. Science now corroborated color's power to manipulate the health and development of the household. "Without the proper application of color to home decoration," one famous commentator argued, "all effort is vain, all expenditure futile. Properly understood and successfully entreated, it is the most powerful mental influence of the home..." Ignored or misapplied, color could "introduce an element of unrest, to refuse healing to tired nerves and overtasked enemies that lie in wait for the victims of weakness and fatigue." ${ }^{14}$ Certainly Charlotte Perkins Gilman seconded this idea with her story describing how a fatigued woman who spent too many days staring at the wrong color wallpaper might find an enemy lurking behind it. ${ }^{15}$

But it was not only recycled racial hierarchies, American imperialism, and germ theory that inspired the whitewashing. By 1893 color was no longer a trapping of social superiority; it was now diffused through all levels of society. Like any product that oversaturates the market, color's stock plummeted. By the turn of the twentieth century the institutionalization of color was almost a fait accompli as a host of public and private entities, using a methodological mélange of Freudian pseudoscience and studies in the physiognomy of color, declared themselves color's arbiters. 

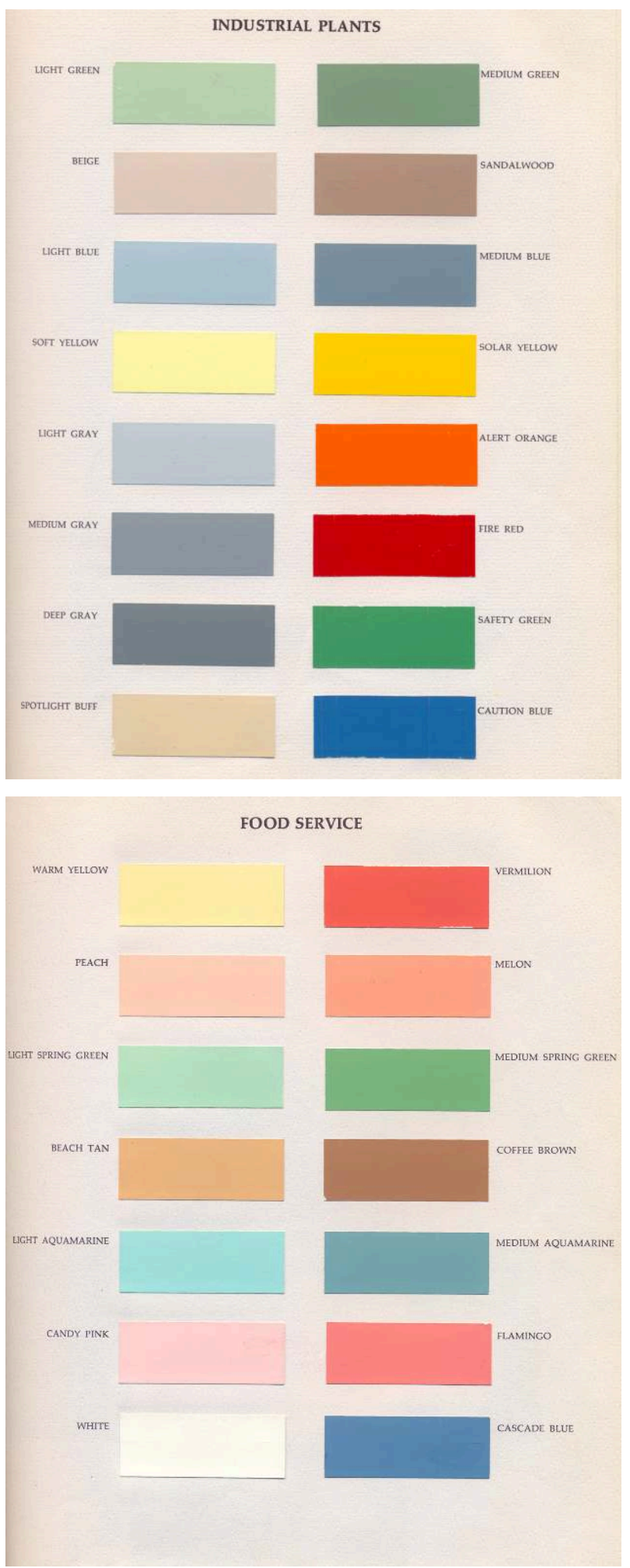

Fig. 25 \& 26. Faber Birren, Color for Interiors, historical and modern. New York: Whitney Library of Design, 1963.

In the nineteenth century, color was not important only to middle-class homemakers and meddling authors. Decorative color's appeal extended to people across the country, socio-economic classes, the urban/rural divide, and in myriad other ways. To the extent that written records and surviving objects let me, I try to let nineteenth-century 
Americans speak for themselves through what they wrote, purchased, designed, manufactured, displayed, and treasured.

\section{ANNEXES}

\section{FIGURE CAPTIONS}

1. Wet-collodion photograph by R. R. Morganweck. Courtesy of Virginia and Michael Mescher, 1999.

2. Swatches of period fabrics photographed in color with a modern camera, and in black and white through the wet collodion process. Scully \& Osterman Studio, 1997.

3. Small dining room, Mount Vernon, Virginia. Ranging in color from light blue-green to deep green-blue, verdigris' translucence comes from the absence of lead in the glaze, its "brushiness" the result of the variable size of the verdigris needle-like particles, which tend to unite in bundles. The applications in these images show five to six layers. Eighteenth-century finishes had a depth, a dimension, to them that modern finely and uniformly factory-milled paints do not have. Courtesy of the Mount Vernon Ladies' Association.

4. First floor bedchamber, Gunston Hall, Mason Neck, Virginia. The home of Washington's contemporary and author of the Virginia Declaration of Rights, George Mason, has also seen its original interior colors restored. Once again this bedchamber glows in verdigris, one of the most fashionable colors of Mason's time. OCourtesy of the Board of Regents of Gunston Hall.

5. Foyer, Adena, Chillicothe, Ohio. The painted surfaces have been restored to their original appearance using data collected during a thorough finish analysis. The floorcloth copies a design and color scheme taken from a period portrait in the local historical society. Courtesy of Ohio Historical Society and Adena Mansion and Gardens Society.

6. Dining room, Adena, Adena, Chillicothe, Ohio. Original wall colors. The Brussels carpet is a period reproduction. Courtesy of Ohio Historical Society and Adena Mansion and Gardens Society.

7. Pin-dot wallpaper, Library, Adena, Chillicothe, Ohio. Restorers found this original wallpaper under wood trim for a doorway that had been installed after Thomas Worthington lived in the house. Courtesy of Ohio Historical Society and Adena Mansion and Gardens Society.

8. Hallway, Ministry Office, 1846, South Union Shaker Village, South Union, Kentucky.

9. The collection's original Hadley chest, Shelburne Museum.

10. The reproduction chest with its original colors applied. Shelburne Museum 
11. Chromolithographed plate illustrating the glaring white so many commentators found objectionable on a country house, from a paint manufacturer's catalogue of 1885 . Athenaeum of Philadelphia.

12. Known as the Warren House, this villa designed by Calvert Vaux sits along the Hudson River in Newburgh, New York.

13. Swatch from a professional dye manual, Thomas Gibson's American Practical Dyer's Companion of 1878,56 . Courtesy of the Smithsonian Institution Libraries.

14. Two of the hundreds of aniline-based colors produced by laboratories in England, Germany, and France in the years after mauve's discovery. Illustrated in William Crookes, A Practical Handbook of Dyeing and Calico-Printing, London, Longmans, Green, and Co., 1874.

15. Appliqué quilt, Baltimore album style, 1854 , executed predominantly in reds and greens in the most popular appliqué style of the era. Private collection.

16. Detail of a heavily embroidered central block.

17. High-style crazy quilt in silks, velvets, and printed ribbons, heavily embellished with embroidery. Kentucky Museum and Library.

18 \& 19. Chromolithographed trade cards produced by furniture companies in the 1880 s, found in late $19^{\text {th }}$-century scrapbooks. Private collection.

20. A page from a typical scrapbook of the period. Americans collected colorful ephemera in scrapbooks by the millions, some covering every inch of the page's space with color, others attempting to arrange them artistically, as seen here. Private collection.

21. Page of paint chips based on the saturated, "muddy" color schemes illustrated in a chromolithographed painting guide, Portfolio of Modern House Painting Designs, produced by John Lucas \& Co. in 1887. Athenaeum of Philadelphia.

22. The same house illustrated in Fig. 11 but with one of the color schemes recommended to the consuming public in the 1880 s by a paint manufacturer. Athenaeum of Philadelphia.

23. Paper dolls produced by a toy manufacturer in the 1850 s, showing the bright textile palette of the period. Kentucky Museum and Library.

24. Homemade paper dolls of the turn of the twentieth century illustrate the dramatically lightened costume palette after the mid 1890s. Kentucky Museum and Library.

25 \& 26. By the middle of the twentieth century authors like Faber Birren claimed an expertise not only in the historical use of color, but in the psychological impact of its application. Here are two palettes Birren recommended for use in industrial settings. Faber Birren, Color for Interiors, historical and modern, New York, Whitney Library of Design, 1963. 


\section{NOTES}

1. One staff member tells the story of a visitor who became so enraged at the reinterpretation of the house's interior that he appeared to have a heart attack. It was only when he was able to speak again that she learned he was only angry at what he perceived to be the desecration of a home he had been visiting since he was a boy. After hearing stories like this at many historic sites brave enough to try to restore original color schemes I tinkered with a formula for predicting the results of such a change on their various constituencies. I came up with this: duration of previous interpretation $\mathrm{x}$ historical stature of homeowner $\mathrm{x}$ degree of change = degree of public reaction. Clearly the greater the three variables of the formula, the greater the reaction to the change.

2. The disappearance of these early colors at Shaker historic sites resulted from a combination of factors, including prominent turn-of-the-century collectors who stripped the old finishes coincident with a modernist aesthetic that eschewed bright color, and the Shakers' own habitual cleanliness, which meant decades of washing their furniture with lye soap. The cost of restoring original colors-from documentary research, to color sampling and study, to the purchase of new furnishings and their installation-is prohibitive, especially for typically underfunded and understaffed public historical institutions.

3. Ideas of color appropriateness, including how colors might or might not be legitimately juxtaposed, are culturally constructed. Historians Shane and Graham White have argued that persistent Africanisms in slave dress irritated masters who may have felt their affectations were being satirized.

4. Letter to Robert Cary \& Company, June 6, 1768. Washington, George, The writings of George Washington from the original manuscript sources, Electronic Text Center, University of Virginia Library, 2, 489-90.

5. Asa Ellis, The Country Dyer's Assistant, Brookfield, Massachusetts, E. Merriam \& Co., 1798, vii.

6. Letter to John Dunn from George Dunn, January 20, 1841, Dunn family papers, Ross County Historical Society, Chillicothe, Ohio.

7. Calvert Vaux, Villas and Cottages: a series of designs prepared for execution in the United States, New York, Harper \& Brothers, 1857, 16-18.

8. Ibid, 17-18.

9. Downing, A. J., and F. A. Waugh. Landscape Gardening, (New York: J. Wiley \& Sons, 1921), 333. The original date of Downing's essay on this subject was June, 1849.

10. Andrew Jackson Downing, Rural Essays, George William Curtis, ed. , New York, Da Capo Press, 1974, 9.

11. Downing, Landscape Gardening, 386.

12. Owen Jones, The Grammar of Ornament, London, Day and Son, 1856.

13. Coal tar is one by-product of the process used to make coal gas, a fuel used in the United States and which is itself a by-product of the coke industry. Aniline, which can be extracted from coal-tar and in combination with other elements can dye colors, had been discovered in the $1820 \mathrm{~s}$ but until Perkin's discovery had remained "a mere laboratory curiosity, devoid of industrial application." William Crookes, A Practical Handbook of Dyeing and Calico-Printing, London, Longmans, Green, and Co., 1874, 171.

14. Candace Wheeler, ed., Household Art, New York, Harper, 1893, 8.

15. Charlotte Perkins Gilman, The Yellow Wallpaper, New York, Feminist Press, 1973. 
INDEX

Thèmes : Trans'Arts

\section{AUTEUR}

\section{KELLY WRIGHT}

University of Cincinnati, Ohio 